\title{
An Imidazoline Compound Completely Counteracts Interleukin-1 $\beta$ toxic Effects to Rat Pancreatic Islet $\beta$ Cells
}

\author{
Gianpaolo Papaccio, ${ }^{1}$ Ferdinando Nicoletti, ${ }^{2}$ Francesco A. Pisanti, ${ }^{3}$ Michela Galdieri, ${ }^{1}$ \\ and Klaus Bendtzen ${ }^{4}$ \\ ${ }^{1}$ Department of Experimental Medicine, Laboratory of Histology and Embryology, School of Medicine, \\ 2nd University of Naples, Naples \\ ${ }^{2}$ Department of Biomedical Sciences, Section of General Pathology, University of Catania, Catania \\ ${ }^{3}$ Department of Cell Biology, School of Biological Science, University of Calabria, Cosenza, Italy \\ ${ }^{4}$ Institute for Inflammation Research, National University Hospital, Copenhagen, Denmark
}

Accepted July 26, 2002

\begin{abstract}
Background: In vitro studies have demonstrated that interleukin (IL) $-1 \beta$ decreases insulin and DNA contents in pancreatic islet $\beta$ cells, causing structural damage, that it is toxic to cultured human islet $\beta$ cells and that it is able to induce apoptosis in these cells.

Materials and Methods: Isolated rat islets of Langerhans were exposed in vitro to interleukin (IL)- $1 \beta$ and either the imidazoline compound RX871024 (RX) or/and M40403, an Mn-containing superoxide dismutase mimetic (MnSODm). Results: Insulin secretion, on days 1,2 and 3 after challenge with $3 \mathrm{ng} / \mathrm{ml}$ of IL- $1 \beta$, was almost abolished and this was accompanied by an early increase in MnSOD activity. By days 2 and 3, SOD activities were lower than those of untreated controls and NO significantly increased by day 2 . Moreover, IL- $1 \beta$ induced a significant increase
\end{abstract}

in MnSOD transcripts, while iNOS mRNA appeared by days 2 and 3 when MnSOD mRNA was absent. RX blocked all toxic effects of IL- $1 \beta$ by maintaining insulin secretion and islet $\beta$ cell phenotype, including the inhibition of nonspecific proteins and of iNOS induction. In contrast, the MnSODm, failed to counteract iNOS induction as well as the reduced insulin secretion.

Conclusions: In summary, our findings stress that IL- $1 \beta$ induced suppression of insulin secretion may be related to iNOS induction in $\beta$ cells and that $\mathrm{RX}$ can reverse this effect, by maintaining insulin secretion. Oppositely, the MnSODm is not able to restore IL- $1 \beta$-suppressed insulin secretion. Hence, imidazoline compounds may protect $\beta$ cells against damage caused by IL- $1 \beta$-induced free oxygen and nitrogen radicals.

\section{Introduction}

In vitro studies have demonstrated that interleukin (IL) $-1 \beta$ decreases insulin and DNA contents in pancreatic islet $\beta$ cells, ultimately causing structural damage $(1-3)$. IL- $1 \beta$ has also been shown to be toxic to cultured human islet $\beta$ cells and to induce apoptosis in these cells $(4,5)$. The cytotoxic effect of IL- $1 \beta$ is potentiated by other cytokines such as tumour necrosis factor and interferon $\gamma$ $(6,7)$.

Free radicals formed in islet $\beta$ cells during immunoinflammatory diabetogenesis may be involved in cytokine-mediated toxicity (8). For example, administration of superoxide dismutase (SOD), the first cellular defense against toxic free radicals, protects $\beta$ cells from damage induced by alloxan and/or streptozotocin (9-13). In addition, $\beta$ cells contain low levels of SOD, and these further decrease in mice rendered

Address correspondence and reprint requests to: G. Papaccio, Department of Experimental Medicine, Laboratory of Histology and Embryology, Second University of Naples 5 via L. Armanni-80138 Naples (Italy). Phone: +39 0815666015 , fax: +39081 5666014; e-mail: gianpaolo.papaccio@unina2.it diabetic by treatment with multiple low-doses of streptozotocin $(9,14-17)$.

Recombinant IL-1 $\beta$ induces MnSOD in rat pancreatic islets, possibly through a direct action on gene transcription (18). IL-1 $\beta$ also damages mitochondrial DNA in NOD mouse $\beta$ cells, and this is at least in part reduced by aminoguanidine administration, suggesting that inhibition of the inducible form of nitric oxide synthase (iNOS) blocks IL- $1 \beta$-induced damage to these cells $(19,20)$. Indeed, it has been shown that endogenous NO induced by IL- $1 \beta$ in rat islets causes significant DNA damage (21). On the other hand, it has been demonstrated that imidazoline compounds, which are known to promote insulin secretion and raise diacylglycerol levels in rat pancreatic islets, may protect against IL- $1 \beta$-induced $\beta$-cell apoptosis (22-24).

In particular, compounds with an imidazoline moiety are known to promote insulin secretion and release by blocking ATP-dependent $\mathrm{K}^{+}$channels, with a subsequent increase of cytoplasmic free $\mathrm{Ca}^{2}$ concentration (22). These compounds for both their effects on insulin and $\mathrm{Ca}^{2+}$ concentration are of high interest because disturbances in $\mathrm{Ca}^{2+}$ homeostatic control can trigger apoptosis (25). On the other hand, 
IL- $1 \beta$ among the cytokines is the main mediator of $\beta$-cell dysfunction (26) and acts upon islet $\beta$ cell by triggering numerous signals, including NO formation, protease activity and insulin secretion in the cell (27).

Since it is still uncertain to what extent free radicals may contribute to the toxic effect of IL- $1 \beta$ on $\beta$ cells, we studied the effects of an imidazoline compound and an Mn-containing superoxide dismutase mimetic (MnSODm) on the in vitro responses of isolated rat islets to IL- $1 \beta$ with emphasis on the effects on the transcriptional levels and activities of MnSOD, CuZnSOD and total SOD, and expression of iNOS and nitric oxide production.

\section{Materials and Methods \\ Isolation and In Vitro Culture of Islets}

Wistar rats, aged 10-12 weeks, were housed in our facility under standard laboratory conditions with free access to food and water. The islets were isolated as previously described (17). Each pancreas was removed and suspended in buffered Hank's solution at $4^{\circ} \mathrm{C}$, then dissected free from extraneous fat and minced with scissors. The tissue was incubated at $37^{\circ} \mathrm{C}$ with vigorous shaking for 15-20 min in $5 \mathrm{ml}$ of Hank's solution, containing $1.6 \mathrm{mg} / \mathrm{ml}$ of type V collagenase (Sigma, Milan, Italy). After centrifugation (500 g, $15 \mathrm{~min})$, the pellet was washed twice and resuspended in $3 \mathrm{ml}$ Hank's solution in a Petri dish. The islets were isolated on a Ficoll gradient and then handpicked using a stereomicroscope and transferred with a Pasteur pipette (14). The islets were precultured at $37^{\circ} \mathrm{C}$ in a $5 \% \mathrm{CO}_{2}$ humidified air atmosphere for 3-6 days in RPMI 1640 medium (Sigma), supplemented with $10 \%$ fetal calf serum. Free-floating islets, 300 per $3 \mathrm{ml}$ medium, were then cultured for another 3 days with or without $3 \mathrm{ng} / \mathrm{ml}$ of IL-1 $\beta$ (Sigma). The islets were also incubated with or without $150 \mu \mathrm{M}$ the imidazoline compound RX871024 (RX) (Reckitt and Colmar, Kingston upon Hull, UK) (24) or $100 \mu \mathrm{M}$ of M40403 (Metaphore Pharmaceuticals, St. Louis, MI, USA), a low molecular weight MnSODm, which removes superoxide anions and attenuates several parameters of inflammation (28).

\section{Insulin Levels and Rate of Insulin Secretion}

Total insulin levels tested in triplicates in each supernatant were quantitated in $\mathrm{mU} / \mathrm{ml}$ using a RIA kit (Bio Rad, Milan, Italy), whereas insulin synthesis and release were tested by the procedure described by Ling et al. (29). Briefly, islets were washed with Ham's medium F-10, containing $0.5 \%$ BSA and $10 \mathrm{mM}$ HEPES. Labeling was carried outat $37^{\circ} \mathrm{C}$ in multiwell plates (50 islets in $400 \mu \mathrm{l}$ of medium) using Ham's F-10 medium, containing $10 \mathrm{mM}$ glucose, $1 \%$ bovine serum albumin (BSA), $2 \mathrm{mM}$ glutamine, $50 \mu \mathrm{M}$ IBMX, and $250 \mu \mathrm{Ci} / \mathrm{ml} \mathrm{L}-\left(3,5-{ }^{3} \mathrm{H}\right)$ tyrosine (Fluka, Milan, Italy). Insulin synthesis was maximal under these conditions, and total ${ }^{3} \mathrm{H}$-labelled insulin immunoreactivity thus represents total proinsulin synthesis during the $2 \mathrm{~h}$-incubation period. Supernatants were collected after centrifugation and assayed for secreted ${ }^{3} \mathrm{H}$-labelled insulin; the rate of insulin secretion was expressed as $10^{3} \mathrm{dpm} \cdot 10^{3}$ islets $^{-1} \cdot 2 \mathrm{~h}^{-1}$. The islets were washed in Ham's F-10 medium, supplemented with $1 \mathrm{mM}$ L-tyrosine and extracted in $1 \mathrm{ml}$ of $2 \mathrm{mM}$ acetic acid, containing $0.25 \%$ BSA. The cell extracts were assayed for ${ }^{3} \mathrm{H}$-labelled protein, ${ }^{3} \mathrm{H}-$ labelled insulin, and total immunoreactive insulin; the islet insulin content was expressed as $\mathrm{ng} / 10^{3}$ islets.

\section{SOD Activities}

Isolated islets were homogeneized (Ultra Turrax mechanical blender) in 100 volumes of $10 \mathrm{mM}$ phosphate buffer (pH 7.4), supplemented with $30 \mathrm{mM} \mathrm{KCl}$, as previously described (30). Briefly, the homogenates were sonicated for $1 \mathrm{~min}$ at $4^{\circ} \mathrm{C}$ with a Branson B12 sonicator and left for 30 min to allow solubilization of the enzyme. After centrifugation at $20,000 \mathrm{~g}$ for $30 \mathrm{~min}$ at $4^{\circ} \mathrm{C}$, the supernatants were removed and stored at $-70^{\circ} \mathrm{C}$. SOD activities (total SOD, CuZnSOD and MnSOD) were measured in triplicates using the RanSOD kit (Randox ${ }^{\circledR}$, Crumlin, Antrim, UK). This method uses xanthine and xanthine oxidase to generate superoxide radicals which react with 2(4-iodophenyl)-3-(4-nitrophenol)-5-phenyltetrazolium chloride (INT) to form a red formazan dye. The superoxide dismutase activity was measured by percentage inhibition of xanthine to water and molecular oxygen. The results are given as U/mg of protein, a unit being the degree of inhibition of the reaction. The intra-assay coefficient of variation was $<2 \%$. Due to the absence of hemoglobin, there was no need to correct the enzyme activities. The detection limit was $2 \mathrm{U} / \mathrm{mg}$ and total immunoreactive insulin; the islet insulin content was expressed as $\mathrm{ng} / 10^{3}$ islets.

\section{Hydroperoxide Levels}

Supernatant lipids were extracted, and $3.8 \mathrm{ml}$ of 2:1 (vol/vol) chloroform-methanol mixture was added to $0.2 \mathrm{ml}$ of supernatant. The mixture was vigorously mixed (using a vortex) for $2 \mathrm{~min}$ and then $1.0 \mathrm{ml}$ of distilled water, and acidified to $\mathrm{pH} 2.5$ with $0.1 \mathrm{~N} \mathrm{HCl}$, was added. After agitation with a vortex for $2 \mathrm{~min}$, the suspension was centrifuged at 3,000 rpm for $5 \mathrm{~min}$ at $4^{\circ} \mathrm{C}$. The lower chloroform lipid layer was removed, vacuum dried in a Savant RC 100 Speed-Vac concentrator (Savant Instruments, Farmingdale, NY, USA), and resuspended in $100 \mu \mathrm{l}$ HPLC-grade methanol for hydroperoxide measurement. The hydroperoxide content of supernatant was determined with the FOX Version II assay for lipid ROOHs (FOX2). This technique relies on the rapid hydroperoxide-mediated oxidation of $\mathrm{Fe}^{2}$ under acidic conditions. $\mathrm{Fe}^{3}$ forms a chromofore with xylenol orange, which absorbs strongly at $560 \mathrm{~nm}$. FOX2 reagent was prepared by dissolving xylenol orange and ammonium ferrous sulfate in $250 \mathrm{mmol} / \mathrm{l} \mathrm{H}_{2} \mathrm{SO}_{4}$ to final concentrations of 1 and $2.5 \mathrm{mmol} / \mathrm{l}$, respectively. One volume of this concentrated reagent was added to 9 vol of HPLC-grade 
methanol containing $4.4 \mathrm{mmol} / \mathrm{l}$ BHT to make the working reagent, which comprised $250 \mu \mathrm{mol} / \mathrm{L}$ ammonium in $90 \%$ (vol/vol) methanol. The working reagent was routinely calibrated against a solution of $\mathrm{H}_{2} \mathrm{O}_{2}$ of known concentration. Aliquots $(90 \mu \mathrm{l})$ of plasma lipid extracts in HPLC-grade methanol were transferred into $1.5 \mathrm{ml}$ microcentrifuge vials. TPP in methanol $(10 \mu \mathrm{l}$ of $10 \mathrm{mmol} / \mathrm{L})$ was added to the blank samples to selectively reduce ROOHs to hydroxy derivatives having no reactivity with $\mathrm{Fe}^{2}$. Methanol (10 $\mu \mathrm{l})$ was added to the test sample. All vials were then vortex-mixed and incubated at room temperature for $30 \mathrm{~min}$ before the addition of mixing of $900 \mu \mathrm{l} \mathrm{FOX2} \mathrm{reagent.} \mathrm{After} \mathrm{incubation} \mathrm{at} \mathrm{room} \mathrm{tem-}$ perature for a further $30 \mathrm{~min}$, the vials were centrifuged at $12,000 \mathrm{~g}$ for $10 \mathrm{~min}$. The absorbance of the supernatant was then read at $560 \mathrm{~nm}$. Hydroperoxide content in the supernatant samples was determined as a function of the mean absorbance difference of samples with and without elimination of ROOHs by TPP. Intra- and interassay coefficients of variation for this method were 5.0 and $6.8 \%$, respectively.

\section{Nitrite + nitrate Levels}

Isolated islets (150/well) were incubated for $30 \mathrm{~min}$ at $37^{\circ} \mathrm{C}$ in $5 \% \mathrm{CO}_{2}$ in $300 \mathrm{ml} \mathrm{KRB}$ medium $(25 \mathrm{mM}$ HEPES, pH 7.4, $115 \mathrm{mM} \mathrm{NaCl,} 24 \mathrm{mM}$ NaHCO3, $5 \mathrm{mM} \mathrm{KCl}, 2.5 \mathrm{mM} \mathrm{CaCl}_{2}, 1 \mathrm{mM} \mathrm{MgCl}, 3 \mathrm{mM} \mathrm{D}-$ glucose, $0.1 \%$ bovine serum albumin). Nitrite+ nitrate was measured after conversion of nitrate to nitrite with Aspergillus nitrate reductase (Sigma). After mixing $0.1 \mathrm{ml}$ supernatant with $0.1 \mathrm{ml}$ Griess reagent (equal parts of $1.3 \%$ sulfanilamide in $60 \%$ acetic acid and $0.1 \%$ naphthyl-ethylene-diamine $\mathrm{HCl}$ in water) and incubating for $10 \mathrm{~min}$ at room temperature, nitrite was measured at $540 \mathrm{~nm}$ in a Gilford spectrophotometer and compared with a standard curve of known nitrite levels. All determinations were made in triplicates. The intra- and interassay coefficients of variations were $<15 \%$; the detection limit was $2 \mathrm{pmol} /$ islet.

\section{$M n S O D$ and INOS mRNA Levels}

In each of three different experiments, total RNA was extracted from 200-250 rat islets by homogenization in $4 \mathrm{M}$ guanidinium thiocyanate, containing $17 \mathrm{mM}$ sodium N-lauryl-sarcosinate, $25 \mathrm{mM}$ citrate buffer, 0.1 M 2-mercapto ethanol, and a $30 \%$ aqueous emulsion of $0.1 \%$ of Antifoam A (Sigma). RNA was precipitated with ethanol, pelleted, and re-extracted with $8 \mathrm{M}$ guanidine hydrochloride: 0.5 M EDTA (19:1). After pelleting and drying, the samples were extracted twice with phenol: chloroform (1:1) and precipitated with ethanol. cDNA synthesis was carried out from total RNA with Superscript reverse transcriptase kit (Life Technologies, Gibco BRL, Milan, Italy), using oligo (dt) ${ }_{12-18}$ and Moloney murine leukaemia virus reverse transcriptase $(20 \mathrm{U})$ in a $25 \mathrm{ml}$ reaction at $37^{\circ} \mathrm{C}$ for 1.5 hours. The solution containing CDNA was diluted 30, 90, and 270 times in sterile water.
Semiquantitative, reverse transcriptase polymerase chain reaction (RT-PCR) amplification was carried out on the cDNA from each animal using $3 \mu \mathrm{l}$ of each dilution of cDNA in a $20 \mu \mathrm{l}$ reaction with $80 \mathrm{ng}$ of each primer, $0.25 \mathrm{mM}$ of each dNTP, $2.5 \mu \mathrm{Ci}$ of $\left(\alpha-{ }^{32} \mathrm{P}\right)$ dCTP $(3,000 \mathrm{Ci} / \mathrm{mmol}$; DuPont-NEN, Milan, Italy), 1 U of AmpliTaq (Perkin-Elmer/Cetus, Monza, Italy), and $3 \mathrm{mM} \mathrm{MgCl}^{2}$ ), as previously described $(31,32)$.

The oligonucleotide primer sequences for $\mathrm{Mn}$ SOD were:

5'-ATTAACGCGCAGATCATGCAG-3' (forward), and 5' TTTCAGATAGTCAGGTCTGACGTT-3' (reverse)

The oligonucleotide primer sequences for CuZnSOD were:

5'-TTCGAGCAGAAGGCAAGCGGTGAA-3'

(forward), and

5' AATCCCAATCACACCACAAGCCAA-3' (reverse).

The oligonucleotide primer sequences for iNOS were:

5'-AGCTTCTGGCACTGAGTAAAGATA-3' (forward), and

5'TTCTCTGCTCTCAGCTCCAAG-3' (reverse).

Cyclophilin was used as a positive control; the primers were:

5'-GACAGCGAAACTTTCCGTGC-3' (forward), and 5'-TCCAGCCACTCAGTCTTGG-3' (reverse).

The RT-PCR analyses were made in triplicate using a PTC-100 thermal cycler (MJ Research, Watertown, MA, USA), in which samples underwent a 10-min initial denaturing step to activate the DNA polymerase, followed cycling $30 \mathrm{~s}$ at $94^{\circ} \mathrm{C}$, $30 \mathrm{~s}$ at $65^{\circ} \mathrm{C}$, and $1 \mathrm{~min}$ at $72^{\circ} \mathrm{C}$ for 35 cycles. Each gene of interest was amplified along with an internal control gene (cyclophilin). The amplification products, in a first set of experiments were separated on a $1.5 \%$ agarose gel containing ethidium bromide, and compared with DNA reference markers, in order to validate the RT-PCR analysis of each gene and to adjust the PCR conditions (ie., number of cycles). In the subsequent experiments, done in triplicates, PCR products were separated on a $6 \%$ polyacrylamide gel in Tris borate EDTA (TBE) buffer. Band intensities were quantified with an Ultrascan XL Enhanced Laser densitometer (LKB, Bromma, Sweden) and expressed in arbitrary units of optical density (OD). The amount of each product was expressed relative to the internal control gene. PCRs were performed on RT-negative samples to exclude genomic DNA contamination for each cDNA preparation. 


\section{MnSOD and iNOS Protein Synthesis}

Proteins were analyzed by Western blot at the end of each experiment. Newly synthesized proteins were labelled at $37^{\circ} \mathrm{C}$ for $2 \mathrm{~h}$ in $200 \mu \mathrm{l} \mathrm{Ham}$ 's F10 medium, containing $10 \mathrm{mM}$ glucose, $1 \%$ BSA, $2 \mathrm{mM}$ glutamine, $1 \mathrm{mM}$ arginine and $50 \mu \mathrm{Ci} / \mathrm{ml} \mathrm{L}-\left(3,5-{ }^{3} \mathrm{H}\right)-$ tyrosine (Invitrogen, Milan, Italy). After culture, the islets were washed and extracted for $3 \mathrm{H}$-labelled protein as mentioned above. Islets were sonicated in $50 \mu \mathrm{l}$ 5\% SDS, 5\% $\beta$-mercaptoethanol, $80 \mathrm{mM}$ TrisCl (pH 6.8), 5 mM EDTA, $10 \%$ glycerol, and $1 \mathrm{mM}$ phenylmethylsulfonyl fluoride, run on $10 \%$ SDSpolyacrylamide gels, and then electrically transferred to nitrocellulose filters. The filters were incubated with the following antibodies to rat proteins: rabbit anti-iNOS, mouse anti-heat shock protein 70 (HSP70) (1:1,000) (Sigma), rabbit anti-HO-1 (all from Sigma), rabbit anti-MnSOD (kind gift of Laboratory "L. Califano", University of Naples, Federico II $^{\circ}$, Naples, Italy), rabbit anti-GLUT2 (Dako, Milan, Italy), rabbit anti-pancreatic and duodenal homeobox gene (PDX)-1, or goat anti- $\beta$ actin (all from Santa Cruz Biotechnology, Santa Cruz, CA, USA). Horseradish peroxidase-linked Ig were used as secondary antibodies, and the bound peroxidase activity was detected by enhanced chemiluminescence (Amersham, Bucks, Buckinghamshire, UK). The intensities of the bands were quantitated in an Ultrascan XL Enhanced Laser Densitometer (LKB, Bromma, Sweden) and expressed in arbitrary units of optical density (OD).

\section{Statistical Analysis}

Student's t test and ANOVA were used for statistical analyses. $\mathrm{P}$ values $<0.05$ were considered statistically significant.

\section{Results}

\section{Effects of $I L-1 \beta, R X 871024$ and $M 40403$}

on Total Islet Insulin Secretion

Insulin secretion was almost blocked by $3 \mathrm{ng} / \mathrm{ml}$ of IL- $1 \beta$ both with regards to the pre-experimental level $(p<0.001)$ and those on days 1, 2 and 3 of the corresponding untreated controls (Fig. 1). The imidazoline compound RX, but not the MnSODm M40403, reversed this effect and, indeed, significantly $(p<0.001)$ increased the insulin levels compared to controls. When both the imidazoline compound and the SODm were added to IL- $1 \beta$ cultured islets, the total islet insulin secretion was slightly lower with respect to the levels found after the use of $\mathrm{RX}$ by alone, but higher than those observed using the SODm.

\section{Effects of IL-1 $\beta, R X 871024$ and $M 40403$ on Islet SOD Activities}

As shown in Figure 2, the MnSOD activities in rat islets challenged with IL- $1 \beta$ increased considerably on day 1 ( $p<0.001$ compared to day 0 and corresponding day 1 control), but decreased significantly

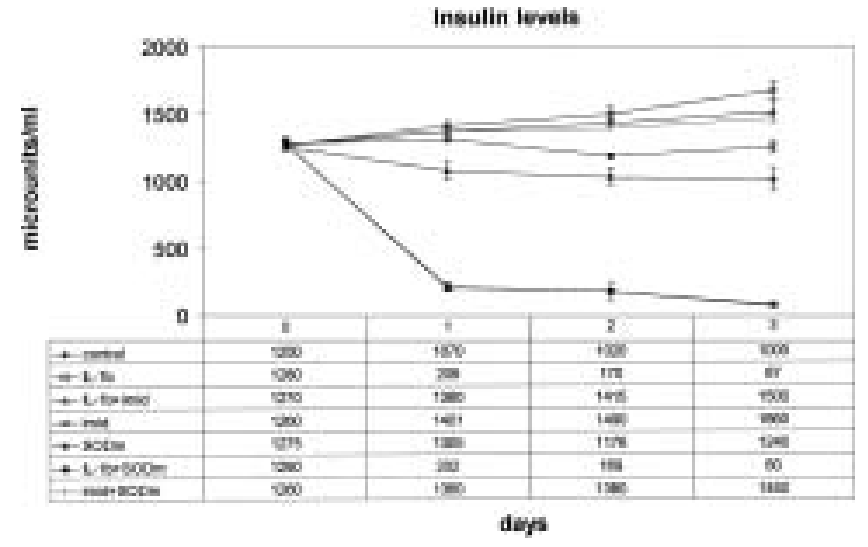

Fig. 1. Effects of IL-1 $\beta$, RX871024 and M40403 on total islet insulin secretion. Islets were isolated from Wistar rats and treated with vehicle alone as controls, IL-1 $\beta$, RX871024, IL-1 $\beta+$ RX871024, M40403, IL-1 $\beta+$ M40403 or IL-1 $\beta+\mathrm{RX871024}+$ M40403. Data are shown as means $\pm \mathrm{SD} ; \mathrm{n}=7 .{ }^{*} p<0.001$ compared with controls.

by days 2 and 3 compared to their respective controls. In contrast, IL- $1 \beta$ induced significantly lower levels of CuZnSOD already by day 1 ( $p<0.001$ compared to day 0 and control), and these levels remained significantly lower than those of controls. Total SOD declined considerably after 3 days of IL- $1 \beta$ treatment to levels considerably below those of controls $(p<0.001$ compared to day 0 and controls).

Figure 2 also shows that while $\mathrm{RX}$ by itself failed to alter the SOD levels, the imidazoline compound counteracted the effect of IL-1 $\beta$ on all SOD levels throughout the course of the studies. When both imidazoline and the SODm were used together with IL-1 $\beta$, MnSOD activity resulted enhanced with values comparable to those found using the SODm alone.

We have also tested the effects of IL- $1 \beta$ on lipid peroxidation by detecting hydroperoxide levels in the supernatants. In this study, the hydroperoxides remained low during the first two days of incubation and treatment with the cytokine (Fig. 3). Then they dramatically increased, up to the end of the culture period (day 6); $p<0.0001$ vs controls and days 0-2). The imidazoline compound does not exert effects upon lipoperoxidation and, when added to the cytokine, completely counteracts its effects upon free radicals and hydroperoxides (Fig. 3). Oppositely, the SODm is not able to counteract the effects of IL- $1 \beta$, and, in addition, by itself, is capable of increasing hydroperoxides $(p<0.001$ vs day 0 and controls).

\section{Effects of $I L-1 \beta, R X 871024$ and $M 40403$ on Islet Nitric Oxide Production}

As shown in Figure 4, the levels of nitrite+nitrate increased dramatically by days 2 and $3(p<0.001$ compared to day 0 and controls). This effect was blocked by simultaneous exposure to RX. 


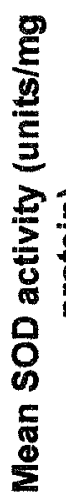

Mn-SOD

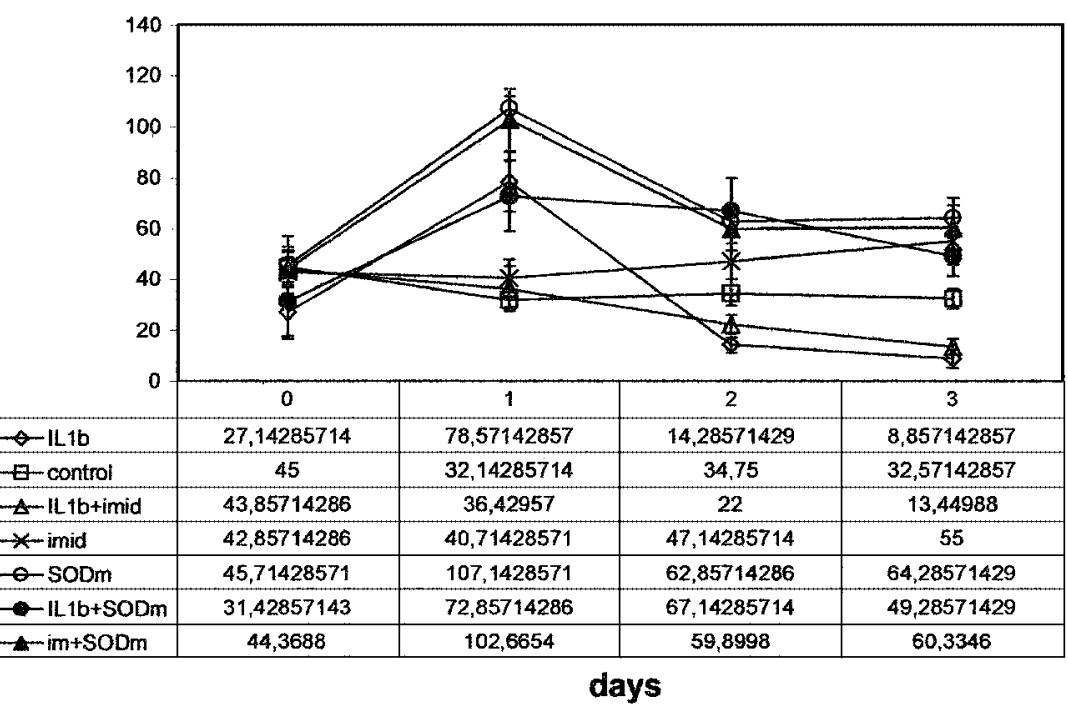

\section{CuZn-SOD}

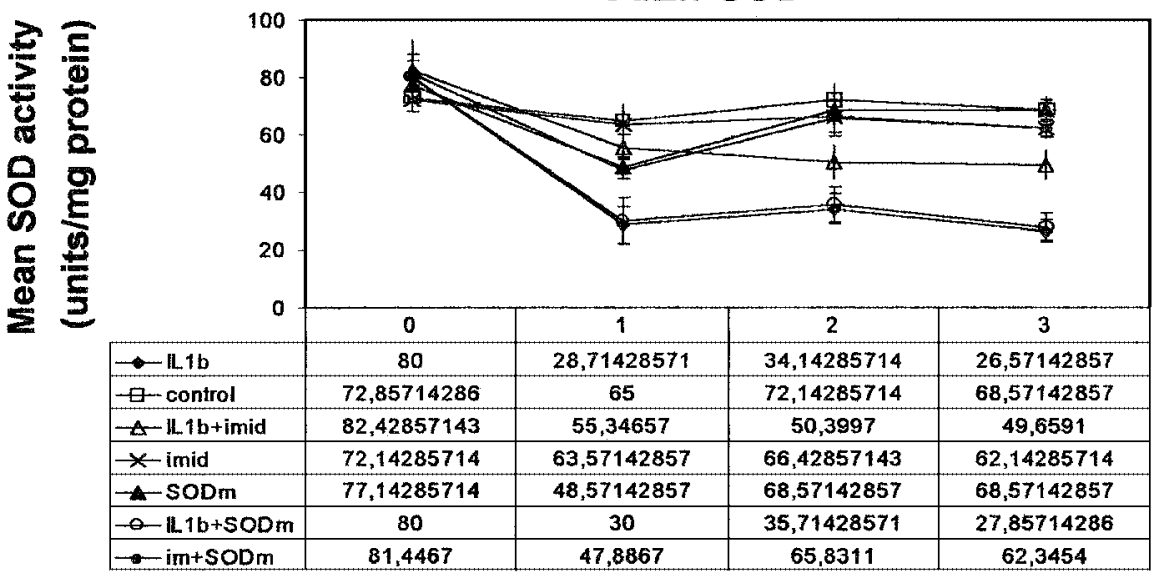

days

足

\section{Total SOD}

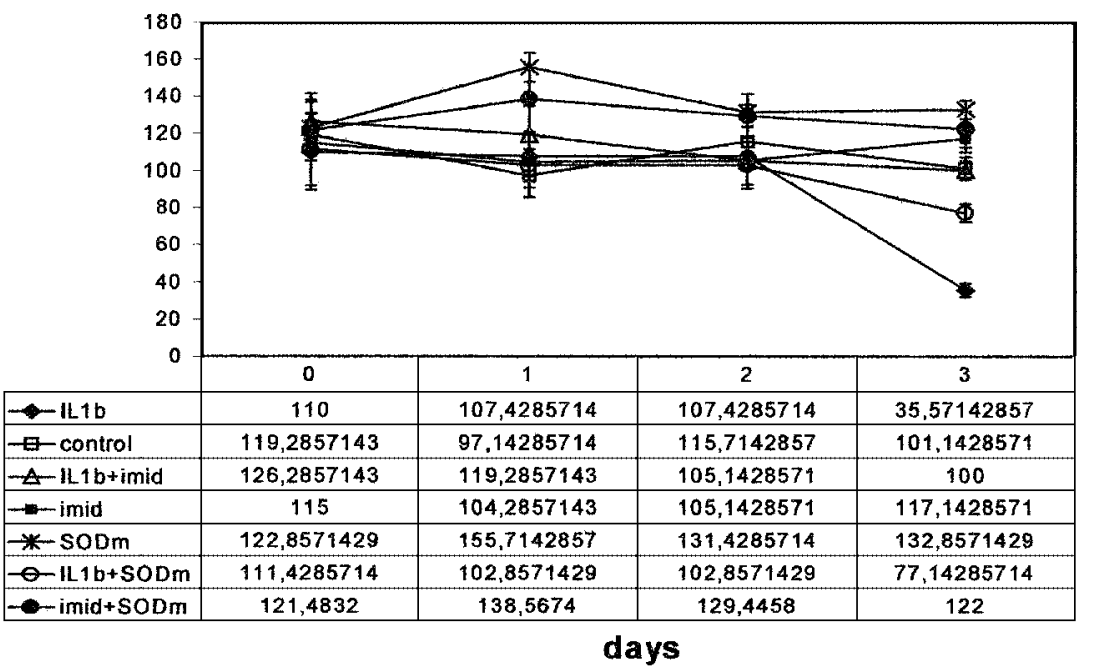

Fig. 2. Effects of IL-1 $\beta$, RX871024 and M40403 on islet SOD activities. The experiments were carried out as in Fig. 1. 


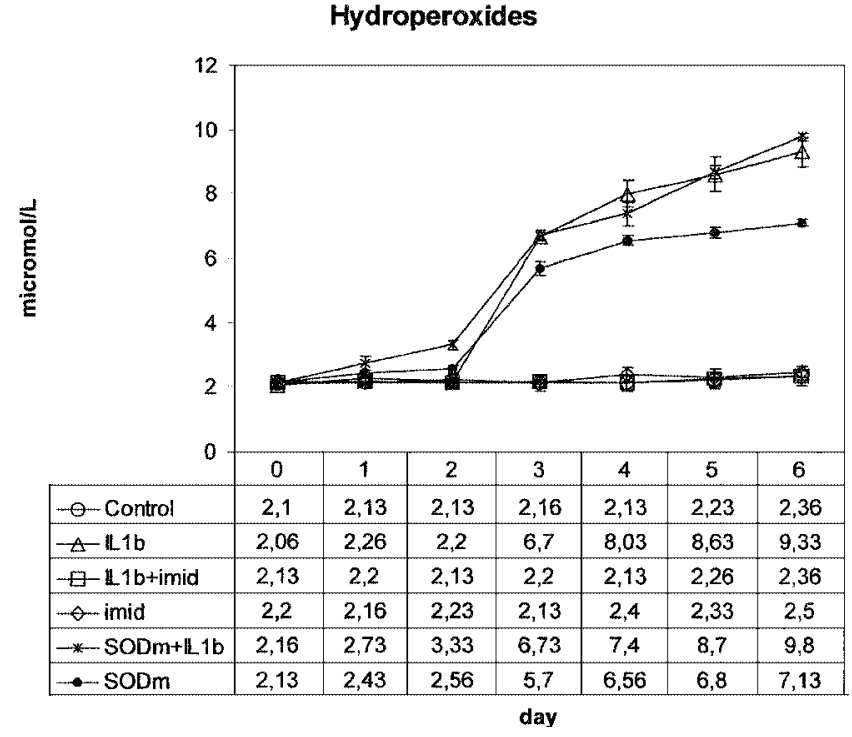

Fig. 3. Effects of IL-1 $\beta$, RX871024 and M40403 on hydroperoxide levels. The experiments were carried out as in Fig. 1.

Effects of IL-1 $\beta, R X 871024$ and M40403 on SOD and iNOS mRNA Levels

RX by itself failed to induce MnSOD, CuZnSOD or total SOD transcripts, both when compared to the pre-experimental transcript levels and to those in controls (data not shown). The compound also failed to induce iNOS mRNA. On the other hand, M40403 by itself induced transcripts of MnSOD (OD $=4.1$ ) as well as of iNOS, though in low amounts $(\mathrm{OD}=1.35)$; OD for cyclophilin mRNA was 4.2.

As shown in Figure 5A, IL- $1 \beta$ induction of MnSOD mRNA was most pronounced on day 1 with a more than 3-fold increase in intensity measured by

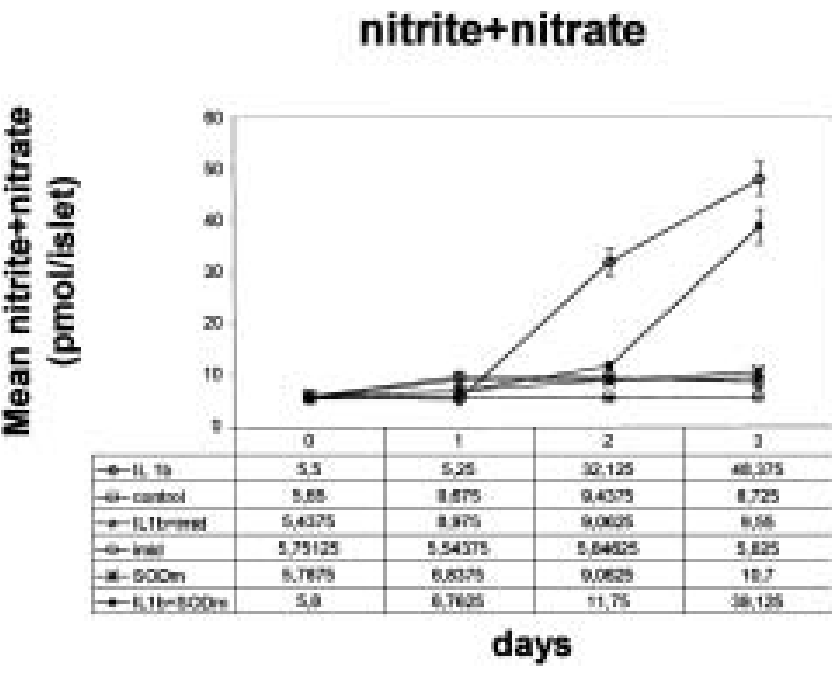

Fig. 4. Effects of IL-1 $\beta$, RX871024 and M40403 on islet nitric oxide production. The experiments were carried out as in Fig. 1. image analysis ( $p<0.01$ vs. day 0$)$. The MnSOD transcripts disappeared by day 3. The CuZnSOD mRNA patterns gradually diminished to barely measurable levels by day 3. In contrast, the transcript for iNOS was absent on day 1 but gradually became very pronounced on day 3 , at a time where signs of structural damage of IL- $1 \beta$ are detectable $(2,3)$. Thus, when IL$1 \beta$ is added to isolated islets in culture, induction of iNOS takes place only when MnSOD activity is undetectable and at a time where the toxic effect of IL- $1 \beta$ becomes apparent.

As shown in Figure 5B, islets cultured with both IL- $1 \beta$ and RX showed an intense MnSOD expression, also on days 2 and 3, where MnSOD expression induced by IL- $1 \beta$ alone is waning (Fig. 5A). This shows that the imidazoline compound is capable of maintaining MnSOD expression even in the presence of IL- $1 \beta$. Figure 5B also shows that RX suppressed IL- $1 \beta$ induction of iNOS by days 2 and 3 .
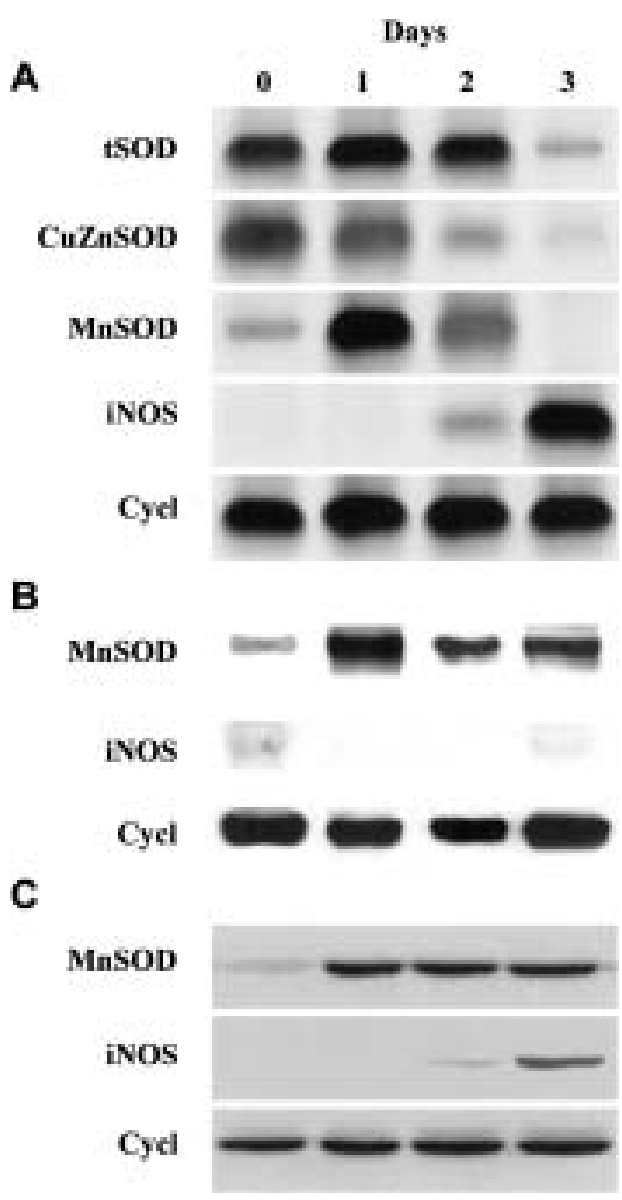

Fig. 5. Effects of IL-1 $\beta$, RX871024 and M40403 on SOD and iNOS mRNA levels. The experiments were carried out as in Fig. 1. The panels show representatives of three independent experiments measuring transcripts of total SOD (tSOD), CuZnSOD, MnSOD and iNOS measured by RT-PCR in the panel A and transcripts of MnSOD and iNOS in panels B and C. Transcripts for cyclophilin $(\mathrm{Cycl})$ were used as controls. (A) Cultures exposed to IL-1 $\beta$. (B) Cultures exposed to IL- $1 \beta+$ RX871024. (C) Cultures exposed to IL-1 $\beta+$ M40403. 
Table 1. Effects of IL-1 $\beta$, RX871024 and M40403 on insulin content and rate of insulin secretion

\begin{tabular}{|c|c|c|}
\hline Treatment & $\begin{array}{l}\text { Islet Insulin Content } \\
\left.\text { (ng/10 } 10^{3} \text { cells }\right)\end{array}$ & $\begin{array}{l}\text { Rate of Insulin Secretion } \\
\left(10^{3} \mathrm{dpm} \cdot 10^{3} \text { cells }^{-1} \cdot 2 \mathrm{~h}^{-1}\right)\end{array}$ \\
\hline a) Controls & $16.5 \pm 2.4$ & $15.0 \pm 0.9$ \\
\hline b) $+\mathrm{IL}-1 \beta$ & $\begin{array}{c}10.5 \pm 2.6 \\
(p<0.05 \text { vs. } a)\end{array}$ & $\begin{array}{c}11.0 \pm 0.9 \\
(p<0.01 \text { vs. } a)\end{array}$ \\
\hline c) $+\mathrm{IL}-1 \beta+\mathrm{RX871024}$ & $\begin{array}{c}18.1 \pm 3.4 \\
(p<0.05 \text { vs. } b)\end{array}$ & $\begin{array}{c}18.6 \pm 3.6 \\
(p<0.02 \text { vs. } b)\end{array}$ \\
\hline d) $+\mathrm{IL}-1 \beta+\mathrm{M} 40403$ & $\begin{array}{c}11.0 \pm 1.7 \\
(p<0.05 \text { vs. } c)\end{array}$ & $\begin{array}{c}11.5 \pm 1.6 \\
(p<0.05 \text { vs. } c)\end{array}$ \\
\hline e) $+\mathrm{IL}-\mathrm{l} \beta+\mathrm{RX} 871024+\mathrm{M} 40403$ & $\begin{array}{c}12.4 \pm 2.2 \\
(p<0.05 \text { vs. } c)\end{array}$ & $\begin{array}{c}13.6 \pm 2.4 \\
(p<0.05 \text { vs. } c)\end{array}$ \\
\hline
\end{tabular}

Data are means \pm SD of three independent experiments, each performed in triplicate.

As shown in Fig. 5C, islets cultured with both IL- $1 \beta$ and M40403 showed a moderate but largely unaltered MnSOD expression on days 1 to 3. M40403 was unable to counteract the IL- $1 \beta$ stimulation of iNOS by days 2 and 3 . Adding to IL- $1 \beta$-cultured islets both the imidazoline compound and the SODm, the results (data not shown) were comparable with those obtained using only the SODm.

\section{Effects of IL-1 $\beta, R X 871024$ and M40403 on Islet Synthesis} and Release of Insulin

As shown in Table 1, IL- $1 \beta$ significantly decreased both insulin content and rate of secretion. This effect was counteracted and even overcompensated by RX. The table also shows that M40403 was unable to counteract the suppressive effect of the cytokine and that the use of both the imidazoline compound and of the SODm only partially reduces the effects of RX.

\section{Effects of IL-1 $\beta, R X 871024$ or M40403 on MnSOD} and iNOS Protein Synthesis

As shown in Table 2, IL- $1 \beta$ increased the synthesis of both MnSOD and iNOS proteins, and addition of RX slightly (MnSOD) or completely reversed (iNOS) this effect. Moreover it decreased the levels of GLUT2 and PDX-1 proteins. When M40403 was added to these cultures, the levels of MnSOD were even higher than in cultures with IL- $1 \beta$ alone, and the levels of iNOS were significantly elevated compared to those in cultures of IL-1 $\beta$-exposed islets added RX alone. Interestingly, the imidazoline compound $\mathrm{RX}$ was able to maintain at high levels the expression of islet $\beta$ cell specific proteins, including GLUT2 and PDX-1: in fact their levels were always comparable to those found in controls or slightly higher, further demonstrating such a protective effect on islet $\beta$ cells. The latter is of some evidence in order to understand the mechanism of action of RX. Actually it exerts its activity upon islet $\beta$ cells by blocking two main IL- $1 \beta$ effects, including insulin impairment and production of islet $\beta$ cell nonspecific proteins. Both abilities of the imidazoline compound in counteracting those toxic effects of IL-1- $\beta$ are addressed to preserve the normal islet $\beta$ cell phenotype. When the SODm and the imidazoline are used together, the effects on the protein synthesis are almost comparable to those obtained using the SODm alone.

\section{Discussion}

SOD is a group of enzymes known to protect cells against toxic oxygen radicals. These enzymes convert superoxide to molecular oxygen, and hydrogen peroxide is subsequently converted to water and oxygen by catalase and various peroxidases. By removing superoxide, SOD prevents the formation of the highly toxic hydroxyl radical, the reaction of which probably explains much of the tissue damage that accompanies superoxide and hydrogen peroxide formation. Indeed, generation of free oxygen radicals has been suggested to mediate at least part of the toxicity of IL- $1 \beta$ on islet $\beta$ cells $(8,11,12)$, and these cells contain relatively low levels of SOD (14). Furthermore, streptozotocin-induced diabetes as well as the spontaneous development of type $1 \mathrm{di}-$ abetes in animal models are associated with even lower levels of SOD, and administration of scavengers has been found to counteract this reduction (13,15-17).

As inhibition of $\beta$ cell functions may be related to IL- $1 \beta$ 's ability to induce reactive oxygen species, the induction of MnSOD has been thought as part of the initial $\beta$ cell response to the cytokine. IL- $1 \beta$ also increases the production of nitric oxide, and inhibitors of nitric oxide have been shown by some investigators to counteract the effects of IL- $1 \beta$ on $\beta$ cells $(33,34)$. It is however still an open question whether nitric oxide is an important mediator of the toxic actions of IL- $1 \beta$, although recent studies show that stable 
Table 2. Effects of IL-1 $\beta$, RX871024 or M40403 on MnSOD and iNOS protein synthesis

\begin{tabular}{|c|c|c|c|}
\hline Treatment & $\begin{array}{l}\text { MnSOD } \\
\text { (OD) }\end{array}$ & $\begin{array}{l}\text { INOS } \\
\text { (OD) }\end{array}$ & $\begin{array}{l}\beta \text {-actin } \\
\text { (OD) }\end{array}$ \\
\hline a) Controls & $20 \pm 1.3$ & 0 & $11.8 \pm 0.4$ \\
\hline b) $+\mathrm{IL}-\mathrm{l} \beta$ & $\begin{array}{c}45.8 \pm 3.1 \\
(p<0.001 \text { vs. } a)\end{array}$ & $\begin{array}{c}17.5 \pm 2.2 \\
(p<0.001 \text { vs. a) }\end{array}$ & $12.7 \pm 2.1$ \\
\hline c) $+\mathrm{IL}-\beta+\mathrm{RX871024}$ & $\begin{array}{c}37 \pm 2.4 \\
(\mathrm{p}<0.02 \text { vs. } b)\end{array}$ & $\begin{array}{c}0.3 \pm 0.5 \\
(p<0.001 \text { vs. } b)\end{array}$ & $12.5 \pm 2.0$ \\
\hline d) $+\mathrm{IL}-\mathrm{l} \beta+\mathrm{M} 40403$ & $\begin{array}{c}64 \pm 6.1 \\
(p<0.02 \text { vs. b) }\end{array}$ & $\begin{array}{c}13.2 \pm 3.0 \\
(p<0.02 \text { vs. } b)\end{array}$ & $12.7 \pm 2.1$ \\
\hline e) $+\mathrm{IL}-1 \beta+\mathrm{RX871024}+\mathrm{M} 40403$ & $\begin{array}{c}62 \pm 7.8 \\
(p<0.002 \text { vs. } c)\end{array}$ & $\begin{array}{c}9.8 \pm 2.2 \\
(\mathrm{p}<0.002 \text { vs. } \mathrm{b})\end{array}$ & $12.2 \pm 2.0$ \\
\hline Treatment & $\begin{array}{l}\text { GLUT2 } \\
\text { (OD) }\end{array}$ & $\begin{array}{l}\text { PDX-1 } \\
\text { (OD) }\end{array}$ & $\begin{array}{l}\beta \text {-actin } \\
\text { (OD) }\end{array}$ \\
\hline a) Controls & $34 \pm 2.5$ & $29 \pm 3.2$ & $12.6 \pm 0.6$ \\
\hline b) $+\mathrm{IL}-1 \beta$ & $\begin{array}{c}10.1 \pm 1.1 \\
(p<0.001 \text { vs. } a)\end{array}$ & $\begin{array}{c}6.5 \pm 0.8 \\
(\mathrm{p}<0.001 \text { vs. } a)\end{array}$ & $12.8 \pm 1.1$ \\
\hline c) $+\mathrm{IL}-1 \beta+\mathrm{RX871024}$ & $\begin{array}{c}39 \pm 2.0 \\
(p<0.001 \text { vs. } b)\end{array}$ & $\begin{array}{c}30.3 \pm 1.5 \\
(p<0.001 \text { vs. } b)\end{array}$ & $12.0 \pm 1.0$ \\
\hline d) $+\mathrm{IL}-\mathrm{l} \beta+\mathrm{M} 40403$ & $\begin{array}{c}16.4 \pm 2.1 \\
(p<0.01 \text { vs. } b)\end{array}$ & $\begin{array}{c}11.6 \pm 1.2 \\
(\mathrm{p}<0.002 \text { vs. } \mathrm{b})\end{array}$ & $13.2 \pm 1.5$ \\
\hline e) + IL-1 $\beta+\mathrm{RX871024}+\mathrm{M} 40403$ & $\begin{array}{c}21.8 \pm 3.8 \\
(\mathrm{p}<0.01 \text { vs. } \mathrm{C})\end{array}$ & $\begin{array}{c}18.2 \pm 2.0 \\
(\mathrm{p}<0.01 \text { vs. } \mathrm{c})\end{array}$ & $13.2 \pm 1.8$ \\
\hline
\end{tabular}

Data are means \pm SD of three independent experiments, each performed in triplicate.

expression of MnSOD reduces the production of nitric oxide and prevents IL- $1 \beta$-induced damage to insulinoma cells (31). It has been also suggested that activation of SOD and subsequent removal of superoxide might also reduce the accumulation of nitric oxidederived toxic products induced by $\operatorname{IL}-1 \beta(18,35)$. Other data indicate that nitric oxide may be toxic to cells by combining with superoxide (36). This would lead to the formation of peroxynitrite anions, which decompose when protonated into the toxic hydroxyl radical. CuZnSOD seems to be involved in the scavenging of superoxide anions as well. In contrast to MnSOD, however, it does not appear to be associated with nitric oxide induced toxicity $(20,31)$.

In this study we have also demonstrated that an increase of hydroperoxides, which are signals of an ongoing lipoperoxidation, takes place, evidencing that the cytokine acts upon islet $\beta$ cells by involving hydroxyl radicals, which lead to an increase of lipoperoxidation. In particular, we have evidenced that the imidazoline compound is capable of counteracting the effects of the cytokine upon free radicals and hydroperoxides, while the SODm does not. In addition, an increase of lipoperoxidation is also seen when adding the SODm alone to cultures. This demonstrates that an increase in superoxide removal without an increase of catalase and glutathione peroxidase activities, lead to an accumulation of the bioproducts of the MnSOD, namely $\mathrm{H}_{2} \mathrm{O}_{2}$ and $\mathrm{O}_{2}$, which can explain the increase in hydroperoxides and lipoperoxidation.

The present in vitro observations agree with and extend previous findings of an early increase in MnSOD activity after exposure of isolated islets to IL- $1 \beta(18,37,38)$. We could confirm that MnSOD activity increased transiently upon in vitro challenge with $3 \mathrm{ng} / \mathrm{ml}$ of IL-1 $\beta$. However, the activity of the enzyme fell significantly after 2 and 3 days of exposure to the cytokine, coinciding in time with the impairment of $\beta$ cell functions (11). These observations were substantiated by the pronounced levels of MnSOD transcripts found during the first day of culture with IL- $1 \beta$ and the subsequent gradual decrease to levels below detection. Moreover, IL- $1 \beta$ increased significantly the levels of both iNOS mRNA and nitrite + nitrate only after 2 days of culture, at the time where the MnSOD transcripts disappeared and the enzyme fell to barely detectable levels.

An imidazoline compound, RX871024, completely counteracted all the negative effects of IL- $1 \beta$, ie., on insulin total levels, rate of secretion and on islet insulin contents, as well as on iNOS and nitrite+ nitrate levels. This agrees with the recently described 
ability of RX to inhibit the apoptotic effect of IL- $1 \beta$ by decreasing NO production and by reducing iNOS expression (24). On the other hand it has been also shown that imidazoline compounds by itself do not trigger apoptosis and are not toxic for islet $\beta$ cells (24). However, RX in our study did not enhance, by itself, MnSOD activity, suggesting that the ability of IL- $1 \beta$ to induce MnSOD is linked to processes not affected by imidazoline. This is further substantiated by the failure of M40403, an Mn-containing superoxide dismutase mimetic (MnSODm) to counteract the cytotoxic effect of the cytokine even though it enhanced MnSOD. Furthermore, RX efficaciously counteracted IL- $1 \beta$-induced synthesis of iNOS, but not of MnSOD, at the protein level and maintained or slightly enhanced the levels of islet $\beta$ cell specific proteins, including GLUT2 and PDX-1. Taken together these findings highly evidenced that the imidazoline compound exerted a direct effect upon insulin secretion and $\beta$-cell activity and specific function, in agreement with the insulinotropic activity recently found in the GK rat (39). Interestingly, the imidazoline compound RX was able to maintain at high levels the expression of islet $\beta$ cell specific proteins, including GLUT2 and PDX-1: this is of some relevance to better understand the mechanism of action of the compound. Actually, it exerts its activity upon islet $\beta$ cells by early blocking IL$1 \beta$ cytotoxic effects, such as insulin impairment and islet $\beta$ cell nonspecific protein induction. $\mathrm{RX}$ activity is, therefore, addressed to preserve the normal islet $\beta$ cell phenotype. The latter must be taken into consideration also in view of the anti-inflammatory activity of imidazoline agents recently found by some authors (40). In fact, it has been observed that imidazoline compounds exert their anti-inflammatory activity inhibiting iNOS induction, as well as NO levels, by a direct action on intracellular signal transduction (40).

We can stress that our results have demonstrated that imidazoline, other than promoting insulin production/secretion, was able to counteract the IL-1 $\beta$ induction of iNOS and NO. Moreover, imidazoline, by maintaining an islet $\beta$ cell differentiate phenotype, possibly exerted through its insulinotropic activity, seems to be capable to give the cell a lesser susceptibility to cytotoxicity, also through maintaining high MnSOD activity.

The present findings make RX871024 and most likely other imidazoline compounds interesting candidates for the prevention/treatment also of type 1 diabetes mellitus. We are presently studying the in vivo effect of the compound, using the NOD mouse model of type 1 diabetes. In summary, IL- $1 \beta$, at a dosage causing significant inhibition of insulin secretion, induced iNOS expression and nitrite + nitrate production in $\beta$ cells. An imidazoline compound effectively counteracted these effects, by stimulating insulin production and secretion and possibly by preventing late MnSOD suppression. This may contribute to cellular resistance to the deleterious effect of IL- $1 \beta$, also by neutralizing superoxide and nitric oxide generation. The results suggest that imidazoline compounds may be used as pharmacological agents to prevent the development of type 1 diabetes.

\section{Acknowledgments}

This work was partly supported by the Italian Ministry for University and Research and by the Danish Biotechnology Program.

\section{References}

1. Bendtzen K, Mandrup-Poulsen T, Nerup J, et al. (1986) Cytotoxicity of human pI 7 interleukin-1 for pancreatic islets of Langerhans. Science 232: 1545-1547.

2. Sandler S, Andersson A, Hellerstrom C. (1987) Inhibitory effects of interleukin 1 on insulin secretion, insulin biosynthesis, and oxidative metabolism of isolated rat pancreatic islets. Endocrinology 121: 1424-1431.

3. Mandrup-Poulsen T, Egeberg J, Nerup J, et al. (1987) Ultrastructural studies of time-course and cellular specificity of interleukin-1 mediated islet cytotoxicity. Acta Pathol. Microbiol. Immunol. Scand. Sect. C 95: 55-63.

4. Rabinovitch A, Baquerizo H, Sumoski W. (1990) Cytotoxic effects of cytokines on islet beta-cells: evidence for involvement of eicosanoids. Endocrinology 126: 67-71.

5. Loweth AC, Williams GT, James RF, et al. (1998) Human islets of Langerhans express Fas ligand and undergo apoptosis in response to interleukin-lbeta and Fas ligation. Diabetes 47: 727-732.

6. Mandrup-Poulsen T, Bendtzen K, Dinarello CA, Nerup J. (1987) Human tumor necrosis factor potentiates human interleukin 1-mediated rat pancreatic $\beta$-cell cytotoxicity. J. Immunol. 139: 4077-4082.

7. Pukel C, Baquerizo H, RAbinovitch A. (1988) Destruction of rat islet cell monolayers by cytokines. Synergistic interactions of interferon-gamma, tumor necrosis factor, lymphotoxin, and interleukin 1. Diabetes 37: 133-136.

8. Eizirik DL, Flodström M, Karlsen AE, Welsh N. (1996) The harmony of the spheres: Inducible nitric oxide synthase and related genes in pancreatic beta cells. Diabetologia 39: 875890.

9. Malaisse WJ, Malaisse-Lagae F, Sener A, Pipeleers DG. (1982) Determinants of the selective toxicity of alloxan to the pancreatic B cell. Proc. Natl. Acad. Sci. USA 79: 927-930.

10. Gandy SE, Buse MG, Crouch RK. (1982) Protective role of superoxide dismutase against diabetogenic drugs. J. Clin. Invest. 70: 650-658.

11. Nerup J, Mandrup-Poulsen T, Mølvig J, et al. (1988) Mechanisms of pancreatic beta-cell destruction in type I diabetes. Diab. Care 11 (Suppl. 1), 16-23.

12. Sumoski W, Baquerizo H, Rabinovitch A. (1989) Oxygen free radical scavengers protect rat islet cells from damage by cytokines. Diabetologia 32: 792-796.

13. Papaccio G. (1991) Prevention of low dose streptozotocininduced diabetes by acetyl- homocysteine-thiolactone. Diabetes Res. Clin. Pract. 13: 95-102.

14. Grankvist K, Marklund SL, Taljedal IB. (1981) CuZnsuperoxide dismutase, Mn-superoxide dismutase, catalase and glutathione peroxidase in pancreatic islets and other tissues in the mouse. Biochem. J. 199: 393-398.

15. Papaccio G, Pisanti FA, Frascatore S. (1986) Acetyl-homocysteine-thiolactone-induced increase of superoxide dismutase counteracts the effect of subdiabetogenic doses of streptozocin. Diabetes 35: 470-474.

16. Pisanti FA, Frascatore S, Papaccio G. (1988) Superoxide dismutase activity in the BB rat: a dynamic time-course study. Life Sci. 43: 1625-1632. 
17. Papaccio G, Frascatore S, Pisanti FA, et al. (1995) Superoxide dismutase in the nonobese diabetic (NOD) mouse: a dynamic time-course study. Life Sci. 56: 2223-2228.

18. Borg LAH, Cagliero E, Sandler S, et al. (1992) Interleukin-1 $\beta$ increases the activity of superoxide dismutase in rat pancreatic islets. Endocrinology 130: 2851-2857.

19. Nicoletti F, Di Marco R, Barcellini W, et al. (1994) Protection from experimental autoimmune diabetes in the non-obese diabetic mouse with soluble interleukin-1 receptor. Eur. J. Immunol. 24: 1843-1847.

20. Wilson GL, Patton NJ, LeDoux SP. (1997) Mitochondrial DNA in beta-cells is a sensitive target for damage by nitric oxide. Diabetes 46: 1291-1295.

21. Delaney CA, Green MH, Lowe JE, Green IC. (1993) Endogenous nitric oxide induced by interleukin- $1 \beta$ in rat islets of Langerhans and HIT-T15 cells causes significant DNA damage as measured by the 'comet' assay. FEBS Lett. 333: 291-295.

22. Zaitsev SV, Efanov AM, Efanova IB, et al. (1996) Imidazoline compounds stimulate insulin release by inhibition of K(ATP) channels and interaction with the exocytotic machinery. Diabetes 45: 1610-1618.

23. Efanov AM, Zaitsev SV, Berggren PO, Mest HJ, Efendic S. (2001) Imidazoline RX871024 raises diacylglycerol levels in rat pancreatic islets. Biochem. Biophys. Res. Commun. 281: 1070-1073.

24. Zaitsev SV, Appelskog IB, Kapelioukh IL, et al. (2001) Imidazoline compounds protect against interleukin $1 \beta$-induced beta-cell apoptosis. Diabetes $\mathbf{5 0}$ (Suppl 1): S70-S76.

25. Efanova IB, Zaitsev SV, Zhivotovski B, et al. (1998) Glucose and tolbutamide induce apoptosis in pancreatic $\beta$ cell: a process dependent on intracellular $\mathrm{Ca}^{2+}$ concentration. J. Biol. Chem. 273: 33501-33507.

26. Eizirik DL, Flodstrom M, Karlsen AE, Welsh N. (1996) The harmony of the spheres: inducible nitric oxide sythase and related genes in pancreatic beta cells. Diabetologia 39: 875890.

27. Sjöholm Å. (1998) Aspects of the involvement of interleukin1 and nitric oxide in the pathogenesis of insulin-dependent diabetes mellitus. Cell. Death. Differ. 5: 461-468.

28. Salvemini D, Mazzon E, Dugo L, et al. (2001) Pharmacological manipulation of the inflammatory cascade by the superoxide dismutase mimetic, M40403. Br. J. Pharmacol. 132: 815-827.
29. Ling Z, In't Veld PA, Pipeleers DG. (1993) Interaction of interleukin-1 with islet $\beta$-cells. Distinction between indirect, aspecific cytotoxicity and direct, specific functional suppression. Diabetes 42: 56-65.

30. McCord JM, Fridovich I. (1969) Superoxide dismutase. An enzymic function for erythrocuprein (hemocuprein). J. Biol. Chem. 244: 6049-6055.

31. Hohmeier HE, Thigpen A, Tran VV, et al. (1998) Stable expression of manganese superoxide dismutase (MnSOD) in insulinoma cells prevents IL- $1 \beta$-induced cytotoxicity and reduces nitric oxide production. J. Clin. Invest. 101: 1811-1820.

32. Papaccio G, Pisanti FA, Latronico MVG, et al. (2000) Multiple low-dose and single high-dose treatments with streptozocin do not generate nitric oxide. J. Cell. Biochem. 77: 82-91.

33. Southern C, Schulster D, Green IC. (1990) Inhibition of insulin secretion by interleukin- $1 \beta$ and tumour necrosis factor- $\alpha$ via an L-arginine-dependent nitric oxide generating mechanism. FEBS Lett 276: 42-44.

34. Welsh N, Eizirik DL, Bendtzen K, Sandler S. (1991) Interleukin- $1 \beta$-induced nitric oxide production in isolated rat pancreatic islets requires gene transcription and may lead to inhibition of the krebs cycle enzyme aconitase. Endocrinology 129: 3167-3173.

35. Moncada S, Palmer RMJ, Higgs EA. (1991) Nitric oxide: Physiology, pathophysiology, and pharmacology. Pharmacol. Rev. 43: 109-142.

36. Beckman JS, Bechman TW, Chen J, et al. (1990) Apparent hydroxyl radical production by peroxynitrite: implications for endothelial injury from nitric oxide and superoxide. Proc. Natl. Acad. Sci. USA 87: 1620-1624.

37. Masuda A, Longo DL, Kobayashi Y, et al. (1988) Induction of mitochondrial manganese superoxide dismutase by interleukin 1. Faseb. J. 2: 3087-3091.

38. Wong GH, Goeddel DV. (1988) Induction of manganous superoxide dismutase by tumor necrosis factor: possible protective mechanism. Science 242: 941-944.

39. Efanov AM, Appelskog IB, Abdel-Halim SM, et al. (2002) Insulinotropic activity of the imidazoline derivative RX871024 in the diabetic GK rat. Am. J. Pysiol. Endcorinol. and Metabolism 282: E117-E124.

40. Regunathan S, Feinstein DL, Reis DJ. (1999) Anti-proliferative and anti-inflammatory actions of imidazoline agents: are imidazoline receptors involved? Ann. N. Y. Acad. Sci. 881: 410-419. 